\title{
Influence of Boron Molybdenum and Nickel on Total Dry Matter, Partitioning and Yield of Blackgram (Vigna mungo L. Hepper)
}

\author{
R. Shalem Raju*, Y. Ashoka Rani, B. Sreekanth and D. P. B. Jyothula \\ Department of Crop Physiology, Agricultural College, Bapatla. Acharya N. G. Ranga \\ Agricultural University, Bapatla - 522 101, Andhra Pradesh, India \\ *Corresponding author
}

Keywords

Blackgram, Boron, Molybdenum, Nickel, Total dry matter and yield

Article Info

Accepted:

07 November 2019

Available Online:

10 December 2019

\section{A B S T R A C T}

A field experiment was conducted on the Influence of Boron Molybdenum and Nickel on Total Dry matter and partitioning of blackgram (Vigna mungo L. Hepper) at Agricultural college farm, Bapatla during rabi, 201718. It consisted of eight treatments of micronutrient application viz., control $\left(\mathrm{T}_{1}\right), \mathrm{B}\left(\mathrm{T}_{2}\right)$, Mo $\left(\mathrm{T}_{3}\right)$, Ni $\left(\mathrm{T}_{4}\right), \mathrm{B}+\mathrm{Mo}\left(\mathrm{T}_{5}\right), \mathrm{B}+\mathrm{Ni}\left(\mathrm{T}_{6}\right), \mathrm{Mo}+\mathrm{Ni}\left(\mathrm{T}_{7}\right)$ and $\mathrm{B}+\mathrm{Mo}+\mathrm{Ni}\left(\mathrm{T}_{8}\right)$ with randomized block design concept and replicated thrice. The results revealed that found increased total dry matter with $\mathrm{B}$, Mo and combination treatments $\mathrm{T}_{5}$ to $\mathrm{T}_{8}$. Root and pod biomass increased by Mo alone and combination treatments. Biomass of leaf and total plant increased by both individual and combination treatments. The increase in seed yield over control (1257.1 kg ha ${ }^{-1}$ ) was high in combination of three nutrients (2144.5 $\mathrm{kg} \mathrm{ha}^{-1}$ ) and B+Mo application (1973.0 $\left.\mathrm{kg} \mathrm{ha}^{-1}\right)$. B and Mo individual application also increased the yield by 1.1 and 1.2 folds respectively. Ni application alone had no influence on yield.

\section{Introduction}

Pulse crops are one of the most sustainable crops a farmer can grow. They also contribute to soil quality by fixing nitrogen in the soil. Though pulses are a very popular crop in the developing world, there is a massive gap in productivity between pulse crops inside and outside the developing world. With the promotion of better management techniques, pulse crops can continue to be an excellent choice for farmers in the developing world. Pulse crops play a major role in food security, a role which will only grow in the future. Black gram originated in India, where it has been in cultivation from ancient times and is one of the most highly prized pulses of India. Black gram is very nutritious as it contains high levels of protein, potassium, calcium, iron, niacin, thiamine, and riboflavin. Black gram complements the essential amino acids provided in most cereals and plays an 
important role in the diets of the people of India. Micronutrients are essential elements that are used by plants in small quantities to orchestrate a range of physiological functions. Application of micronutrients increases the yield and quality of agricultural products.

Boron plays a key role in sugar translocation, nodulation, nitrogen fixation, protein synthesis, sucrose synthesis, cell wall composition, membrane stability, $\mathrm{K}^{+}$transport, viability of pollen, pollen germination and pollen tube growth and pollination and seed set. Molybdenum has been shown to help in the nodulation, nitrogen fixation, photosynthesis, nitrogen assimilation, concentration of sugars, particularly reducing sugars, and increase in the ratio of organic phosphorus/inorganic phosphorus. Nickel is an essential micronutrient for plant growth as a constituent of several metallo-enzymes such as urease, superoxide dismutase, NiFe hydrogenases, methyl coenzyme $\mathrm{M}$ reductase, carbon monoxide dehydrogenase, acetyl coenzyme-A synthase, hydrogenases, and RNase-A. Tripathy et al., (1999) found that soil application of B (10 kg ha $\left.{ }^{-1}\right)$, Mo $(1.5 \mathrm{~kg}$ $\left.\mathrm{ha}^{-1}\right)$ and $\mathrm{Zn}\left(25 \mathrm{~kg} \mathrm{ha}^{-1}\right)$ in combination improved leaf area total and dry matter plant $^{-1}$ than alone application. The efficacy of various treatments of boron and molybdenum applied by different methods in mungbean was evaluated by Singh et al., (2014).

\section{Materials and Methods}

A field experiment was conducted to study the Influence of Boron Molybdenum and Nickel on Total Dry matter, partitioning \& Yield of blackgram (Vigna mungo L. Hepper) at Agricultural College Farm, Bapatla during Rabi season of 2017-18. The experiment consisted of 8 treatments viz., $\mathrm{T}_{1^{-}}$no micronutrient application (control), $\mathrm{T}_{2}-$ Borax @ $2.5 \mathrm{~kg} \mathrm{ha}^{-1}, \mathrm{~T}_{3}$ - Ammonium molybdate @ $1.5 \mathrm{~kg} \mathrm{ha}^{-1}, \mathrm{~T}_{4}$ - Nickel chloride@1 kg ha ${ }^{-1}$,
$\mathrm{T}_{5^{-}}$Borax @ $2.5 \mathrm{~kg}$ and Ammonium molybdate@1.5 kg ha ${ }^{-1}, \mathrm{~T}_{6}$ - Borax @2.5 kg and Nickel chloride @1 kg ha ${ }^{-1}, \mathrm{~T}_{7^{-}}$ Ammonium molybdate@1.5 kg and Nickel chloride@1 kg ha-1, $\mathrm{T}_{8^{-}}$Borax @ $2.5 \mathrm{~kg}$, Ammonium molybdate@1.5 kg and Nickel chloride@1 kg ha ${ }^{-1}$ and applied as basal. It was laid in randomized block design and replicated thrice. The soil was neutral in reaction, low in salinity and nitrogen, medium in available phosphorus and organic carbon and very high in potassium. The standard packages of cultural practices were followed throughout crop growth period. The data on the total dry matter accumulation and its partitioning was estimated from the five adjacent uniform sized plants sampled from each treatment in three replications and then separated into roots, stems, leaves and pods. The plant parts were dried to a constant weight in hot-air oven at $80^{\circ} \mathrm{C}$ for two days and the dry weights were recorded and expressed in $g$ plant $^{-1}$. The crop was harvested at physiological maturity and the number of seed collected from the pods obtained from five tagged plants were collected, weighed and expressed as seed yield plant $^{-1}$ in grams. Harvested plants were kept in the field for drying. After drying the pods, total pods from a plot were threshed and the resulted seed yield was calculated for a net plot area and it was computed and analyzed as per the statistical procedures given by Panse and Sukhatme (1985) to hectare and expressed as $\mathrm{kg} \mathrm{ha}^{-1}$.

\section{Results and Discussion}

\section{Root dry matter (g plant $\left.{ }^{-1}\right)$}

Application of micronutrients significantly increased the dry matter accumulation in root Table 1. At $20 \mathrm{DAE}$, it was high in $\mathrm{T}_{8}$ $(\mathrm{B}+\mathrm{Mo}+\mathrm{Ni})$, significantly superior to other treatments. The next higher mass of root was obtained with application of $\mathrm{B}+\mathrm{Mo}\left(\mathrm{T}_{5}\right)$, 
$\mathrm{B}+\mathrm{Ni}\left(\mathrm{T}_{6}\right)$ and $\mathrm{Mo}+\mathrm{Ni}\left(\mathrm{T}_{7}\right)$.

The least increase in root mass over control was obtained with $\mathrm{Ni}\left(\mathrm{T}_{4}\right)$ application. $\mathrm{B}\left(\mathrm{T}_{2}\right)$ and Mo $\left(\mathrm{T}_{3}\right)$ application also resulted in root biomass on par with $\mathrm{B}+\mathrm{Ni}\left(\mathrm{T}_{6}\right)$ and $\mathrm{Mo}+\mathrm{Ni}$ $\left(\mathrm{T}_{7}\right)$ combined application. At $40 \mathrm{DAE}$, it was high in $\mathrm{T}_{8}$, significantly superior to other treatments and it was followed by $\mathrm{T}_{7}, \mathrm{~T}_{5}$. Less increase in root biomass over control was observed with application of micronutrients $\left(\mathrm{T}_{2}, \mathrm{~T}_{3}, \mathrm{~T}_{4}\right)$ alone. The treatments $\mathrm{T}_{5} \& \mathrm{~T}_{6}$ and $\mathrm{T}_{3} \& \mathrm{~T}_{6}$ were found on par in exhibiting the impact on root biomass.

At 60 DAE, root biomass was maximum in $\mathrm{T}_{8}$, which showed parity with $\mathrm{T}_{5}(\mathrm{~B}+\mathrm{Mo}), \mathrm{T}_{7}$ $(\mathrm{Mo}+\mathrm{Ni}) \quad \mathrm{T}_{6}(\mathrm{~B}+\mathrm{Ni})$ and $\mathrm{T}_{3}(\mathrm{Mo})$. It was minimum in control, which was on parity with $\mathrm{T}_{2}$ (B) and $\mathrm{T}_{4}(\mathrm{Ni})$. At harvest, the root biomass maximum in $\mathrm{T}_{8}$ and minimum in $\mathrm{T}_{4}$. The treatments $T_{7} \& T_{5}$ and $T_{3} \& T_{6}$ were found on par in showing the impact on root biomass. Among the micronutrient treatments, root biomass was least in $\mathrm{T}_{4}(\mathrm{Ni})$.

In this study, root biomass increased up to 60 DAE and later declined. At the stage of maximum growth, $\mathrm{B}+\mathrm{Mo}$ and $\mathrm{B}+\mathrm{Mo}+\mathrm{Ni}$ application increased the root biomass over control by 1.4 and 1.5 folds, respectively. Where as in other effective treatments (Mo, $\mathrm{B}+\mathrm{Ni}$ and $\mathrm{Mo}+\mathrm{Ni}$ ), root biomass increased by 1.3 folds. This suggests that individual application of $\mathrm{B}$ and $\mathrm{Ni}$ didn't influence the accumulation of biomass in roots, but when applied in combination of Mo influenced the root biomass considerably. Bhuiyan et al., (2008) reported that application of Mo @ of $1.0 \mathrm{~kg} \mathrm{ha}^{-1}$ increased the fresh and dry weight of the root over control in mungbean. Similar finding was reported by Khan et al., (2014) with Mo in chickpea.

\section{Stem dry matter (g plant $\left.{ }^{-1}\right)$}

Dry matter accumulation in stem increased significantly with application of micronutrients compared to control Table 1. At 20 DAE, among the micronutrient treatments, stem biomass was found high in $\mathrm{T}_{8}$, which was at par with $\mathrm{T}_{5}$ and $\mathrm{T}_{3}$ application. It was low in $\mathrm{T}_{4}$ applied plants. The remaining treatments $\mathrm{T}_{3}, \mathrm{~T}_{5}, \mathrm{~T}_{6}$ and $\mathrm{T}_{7}$ increased the stem biomass at par with each other superior to $\mathrm{T}_{4}$ and inferior to $\mathrm{T}_{8}, \mathrm{~T}_{5}$. At 40 DAE, the influence of $\mathrm{B}$ and $\mathrm{Ni}$ application was on par with control. Among rest of the treatments stem biomass was found high in $\mathrm{T}_{8}$, and low in $\mathrm{T}_{3}$. Application of $\mathrm{B}+\mathrm{Mo}, \mathrm{B}+\mathrm{Ni}$ and $\mathrm{Mo}+\mathrm{Ni}$ recorded the stem biomass on par with each other, superior to $\mathrm{T}_{3}$ and inferior to $\mathrm{T}_{8}$.

At 60 DAE, all micronutrient treatments exhibited highly variable effect on stem biomass in comparison to control. The increase in stem biomass was less in $\mathrm{T}_{6}, \mathrm{~B}$, Mo and Ni treated plants. It was found more in $\mathrm{B}+\mathrm{Mo}+\mathrm{Ni}$ treated plants followed by other combinations $\mathrm{Mo}+\mathrm{Ni}$ and $\mathrm{B}+\mathrm{Mo}$. At harvest stage, the increase in stem biomass was maximum in $\mathrm{T}_{8}$ and minimum in $\mathrm{T}_{3}, \mathrm{~T}_{4}$ and $\mathrm{T}_{6}$. The remaining treatments $\mathrm{T}_{7}, \mathrm{~T}_{5}$ and $\mathrm{T}_{2}$ exhibited the performance to the level of between maximum and minimum. The increase in biomass was 2.0, 1.8 folds with $\mathrm{B}+\mathrm{Mo}+\mathrm{Ni}$ and $\mathrm{Mo}+\mathrm{Ni}$ respectively. Compared to $\mathrm{B}+\mathrm{Ni}$ and $\mathrm{Mo}$ application (1.5 and 1.6 folds, respectively) $\mathrm{B}, \mathrm{Ni}$ and $\mathrm{B}+\mathrm{Mo}$ application resulted in relatively higher increase (1.7 folds).

The increase in stem biomass with application of these three micronutrients could be due to its involvement in plant metabolism and promotion of plant growth with better assimilation and translocation. Similar observations were expressed by Khan et al., (2014) in chickpea, Zahoor et al., (2013) in soybean, Singh et al., (2013) in blackgram and Valenciano et al., (2010) in chickpea with 
response to $\mathrm{Mo}, \mathrm{Mo}, \mathrm{Ni}$ and $\mathrm{B}+\mathrm{Mo}$, respectively.

\section{Leaf dry matter (plant $\left.{ }^{-1} \mathrm{~g}\right)$}

Application of micronutrients B, Mo and $\mathrm{Ni}$ as basal alone and in combinations significantly increased the accumulation of biomass in leaf Table 2. At 20 DAE, micronutrients in combination showed higher leaf biomass than individual application, out of which only Mo treated plants showed increase, while $\mathrm{B}$ and $\mathrm{Ni}$ treated plants were on par with control. At 40 DAE, micronutrient application $\left(\mathrm{T}_{2}\right.$ and $\left.\mathrm{T}_{8}\right)$ increased the leaf biomass, which varied from 3.21 to $4.67 \mathrm{~g} \mathrm{plant}^{-1}$. This increase was maximum in $\mathrm{B}+\mathrm{Mo}+\mathrm{Ni}$ treated plants and minimum in $\mathrm{Ni}$ treated plants which showed parity with $\mathrm{B}+\mathrm{Ni}$, which showed parity with $\mathrm{B}+\mathrm{Ni}$, Mo and B application.

At 60 DAE also, micronutrient treatments increased the leaf biomass over control. The maximum increase in leaf biomass was noticed in $\mathrm{B}+\mathrm{Mo}+\mathrm{Ni}$ treated plants and minimum in plants, treated with $\mathrm{B}, \mathrm{Mo}$ and $\mathrm{Ni}$ alone. The remaining treatments $\mathrm{B}+\mathrm{Mo}$, $\mathrm{Mo}+\mathrm{Ni}$ and $\mathrm{B}+\mathrm{Ni}$ exhibited the performance to the level of between maximum and minimum.

At harvest stage, leaf biomass was high in $\mathrm{B}+\mathrm{Mo}+\mathrm{Ni}$ treated plants, which showed parity with other combination treatments $\left(T_{5}\right.$ to $\left.T_{7}\right)$ and low in Ni treated plants, which was found on par with Mo and B treated plants. Micronutrients application in combination increased the leaf biomass to an extent of 24.4 to 53.8 percent and alone increased it an extent of 14.7 to 15.0 percent.

Increase in leaf biomass in response to B, Mo and $\mathrm{Ni}$ nutrition can be attributed to increase in leaf area, photosynthetic pigments, leaf water status and photosynthetic responses. Enhanced dry matter accumulation in shoots of plants treated with Mo compared to untreated was repeated by Zahoor et al., (2013) in soybean. Singh et al., (2013) reported increase in fresh and dry weight of shoot with nickel upto $50 \mu \mathrm{M}$ over control in blackgram. Similar findings with B application were reported by Rajeev and Dinesh (2014) in greengram.

\section{Pod dry matter (g plant $\left.{ }^{-1}\right)$}

The effect of micronutrient application on pod dry matter was found significant at all days of observation Table 2. At 40 DAE, among the treatments, $\mathrm{B}+\mathrm{Mo}+\mathrm{Ni}$ application showed significantly higher pod dry matter. The next higher values were recorded with other combinations $\mathrm{B}+\mathrm{Ni}, \mathrm{Mo}+\mathrm{Ni}$ and $\mathrm{B}+\mathrm{Mo}$. The pod dry matter was low in control, which showed parity with $\mathrm{B}$ and $\mathrm{Ni}$ application alone. Mo application resulted in pod dry matter superior to control and on par with the treatments $\mathrm{B}+\mathrm{Mo}$ and $\mathrm{Mo}+\mathrm{Ni}$.

At 60 DAE, pod dry matter was found maximum in $T_{8}$, which showed parity with other combination treatments $T_{5}$ to $T_{7}$ and $T_{3}$. The minimum value for dry matter was obtained in control, which was on par with $\mathrm{T}_{2}$ $\& \mathrm{~T}_{4}$. Finally at harvest, pod dry matter obtained was significantly high in the treatments $T_{8}$ and $T_{5}$ compared to control and other treatments. It was low in control, which showed parity with application of $\mathrm{B}$ and $\mathrm{Ni}$ alone. The next high value was recorded in plants treated with $\mathrm{Mo}+\mathrm{Ni}, \mathrm{B}+\mathrm{Ni}$ and $\mathrm{Mo}$ which were on par with one another.

Application of $\mathrm{B}+\mathrm{Mo}$ and $\mathrm{B}+\mathrm{Mo}+\mathrm{Ni}$ enhanced the pod dry matter by 1.4 and 1.5 folds, respectively over control, while $\mathrm{Mo}+\mathrm{Ni}$, $\mathrm{B}+\mathrm{Ni}$ and Mo application enhanced it by 1.3 , 1.3 and 1.2 folds, respectively. 
Table.1 Effect of micronutrients (B, Mo \& Ni) on Root dry matter and stem dry matter $\left(\mathrm{g}\right.$ plant $\left.{ }^{-1}\right)$ in Blackgram

\begin{tabular}{|c|c|c|c|c|c|c|c|c|}
\hline \multirow[t]{2}{*}{ Treatments } & \multicolumn{4}{|c|}{ Root dry matter $\left(\right.$ g plant $\left.^{-1}\right)$} & \multicolumn{4}{|c|}{ Stem dry matter $\left(g_{\text {plant }}{ }^{-1}\right)$} \\
\hline & 20 DAE & 40 DAE & 60 DAE & $\begin{array}{c}\text { At } \\
\text { Harvest }\end{array}$ & 20 DAE & 40 DAE & $60 \mathrm{DAE}$ & At Harvest \\
\hline T1: Control & 0.11 & 0.34 & 0.60 & 0.57 & 0.12 & 0.75 & 1.95 & 2.15 \\
\hline T2: Borax@2.5 Kg ha ${ }^{-1}$ & 0.15 & 0.46 & 0.72 & 0.67 & 0.18 & 0.93 & 3.15 & 3.72 \\
\hline T3: Ammonium molybdate @ $1.5 \mathrm{Kg} \mathrm{ha}^{-1}$ & 0.15 & 0.49 & 0.77 & 0.74 & 0.19 & 1.07 & 3.22 & 3.53 \\
\hline T4: $\mathrm{Ni} \mathrm{Cl}_{2 .} 6 \mathrm{H}_{2} \mathrm{O} @ 1.0 \mathrm{Kg} \mathrm{ha}^{-1}$ & 0.13 & 0.44 & 0.67 & 0.63 & 0.15 & 0.90 & 3.28 & 3.65 \\
\hline $\begin{array}{l}\text { T5: Borax @ 2.5\&Ammonium } \\
\text { molybdate @ } 1.5 \mathrm{Kg} \mathrm{ha}^{-1}\end{array}$ & 0.17 & 0.61 & 0.81 & 0.76 & 0.19 & 1.56 & 3.38 & 3.72 \\
\hline $\begin{array}{c}\text { T6: Borax @ } 2.5 \& \mathrm{Ni}_{\mathrm{Kg} \mathrm{ha}}^{-1} \\
\mathrm{Cl}_{2 .} 6 \mathrm{H}_{2} \mathrm{O} @ 1.0\end{array}$ & 0.16 & 0.56 & 0.79 & 0.74 & 0.18 & 1.38 & 3.11 & 3.28 \\
\hline $\begin{array}{l}\text { T7: Ammonium molybdate @ } 1.5 \& \mathrm{Ni} \\
\mathrm{Cl}_{2 .} 6 \mathrm{H}_{2} \mathrm{O} @ 1.0 \mathrm{Kg} \mathrm{ha}^{-1}\end{array}$ & 0.16 & 0.62 & 0.80 & 0.77 & 0.18 & 1.58 & 3.42 & 3.80 \\
\hline $\begin{array}{l}\text { T8: Borax @ } 2.5 \& \text { Ammonium } \\
\text { molybdate @ } 1.5 \& \mathrm{Ni} \mathrm{Cl}_{2 .} 6 \mathrm{H}_{2} \mathrm{O} @ 1.0 \\
\mathrm{Kg} \mathrm{ha}^{-1} .\end{array}$ & 0.18 & 0.72 & 0.88 & 0.83 & 0.21 & 2.05 & 3.65 & 4.33 \\
\hline $\mathrm{SE}(\mathbf{m}) \pm$ & 0.01 & 0.03 & 0.04 & 0.01 & 0.01 & 0.08 & 0.04 & 0.14 \\
\hline $\mathrm{CD}(\mathbf{0 . 0 5})$ & 0.02 & 0.08 & 0.13 & 0.02 & 0.03 & 0.24 & 0.12 & 0.44 \\
\hline $\mathrm{CV}(\%)$ & 8.80 & 8.06 & 9.77 & 1.85 & 8.68 & 10.90 & 2.14 & 7.08 \\
\hline
\end{tabular}


Table.2 Effect of micronutrients (B, Mo \& Ni) on Leaf dry matter and pod dry matter $\left(\mathrm{g} \mathrm{plant}^{-1}\right)$ in Blackgram

\begin{tabular}{|c|c|c|c|c|c|c|c|}
\hline \multirow[t]{2}{*}{ Treatments } & \multicolumn{4}{|c|}{ Leaf dry matter $\left(\right.$ g plant $\left.^{-1}\right)$} & \multicolumn{3}{|c|}{ Pods dry matter $\left(\right.$ g plant $\left.^{-1}\right)$} \\
\hline & 20 DAE & 40 DAE & 60 DAE & At Harvest & 40 DAE & 60 DAE & At Harvest \\
\hline T1: Control & 0.41 & 2.85 & 3.20 & 2.07 & 0.85 & 5.42 & 7.45 \\
\hline T2: Borax @ $2.5 \mathrm{Kg} \mathrm{ha}^{-1}$ & 0.44 & 3.32 & 3.67 & 2.86 & 1.05 & 5.89 & 8.40 \\
\hline T3: Ammonium molybdate @ $1.5 \mathrm{Kg} \mathrm{ha}^{-}$ & 0.47 & 3.36 & 3.68 & 2.90 & 1.08 & 7.10 & 9.22 \\
\hline T4: $\mathrm{Ni} \mathrm{Cl}_{2 .} 6 \mathrm{H}_{2} \mathrm{O} @ 1.0 \mathrm{Kg} \mathrm{ha}^{-1}$ & 0.43 & 3.21 & 3.70 & 2.76 & 0.97 & 5.56 & 8.07 \\
\hline $\begin{array}{l}\text { T5: Borax @ } 2.5 \& \text { Ammonium } \\
\text { molybdate @ } 1.5 \mathrm{Kg} \mathrm{ha}^{-1}\end{array}$ & 0.52 & 3.72 & 4.08 & 3.60 & 1.20 & 7.78 & 10.37 \\
\hline 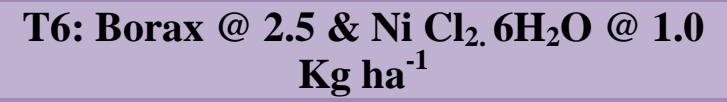 & 0.52 & 3.37 & 3.98 & 3.34 & 1.37 & 7.23 & 9.62 \\
\hline $\begin{array}{l}\text { T7: Ammonium molybdate @ } 1.5 \& \mathrm{Ni} \\
\mathrm{Cl}_{2 .} 6 \mathrm{H}_{2} \mathrm{O} @ 1.0 \mathrm{Kg} \mathrm{ha}^{-1}\end{array}$ & 0.53 & 3.50 & 4.0 & 3.38 & 1.22 & 7.14 & 9.68 \\
\hline 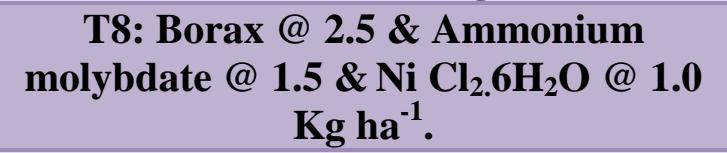 & 0.53 & 4.67 & 4.92 & 3.67 & 1.63 & 8.03 & 11.32 \\
\hline $\mathbf{S E}(\mathbf{m}) \pm$ & 0.02 & 0.09 & 0.09 & 0.19 & 0.07 & 0.43 & 0.36 \\
\hline $\mathrm{CD}(\mathbf{0 . 0 5})$ & 0.06 & 0.28 & 0.29 & 0.57 & 0.21 & 1.43 & 1.10 \\
\hline $\mathrm{CV}(\%)$ & 6.78 & 4.84 & 4.20 & 10.51 & 10.33 & 10.90 & 6.80 \\
\hline
\end{tabular}


Table.3 Effect of micronutrients (B, Mo \& Ni) on Total dry matter $\left(\mathrm{g}\right.$ plant $\left.{ }^{-1}\right)$ and seed yield plant ${ }^{-1}$ and kg ha $^{-1}$ in $\mathrm{Blackgram}$

\begin{tabular}{|c|c|c|c|c|c|c|}
\hline \multirow[t]{2}{*}{ Treatments } & \multicolumn{4}{|c|}{ Total dry matter $\left(\right.$ g plant $\left.^{-1}\right)$} & \multicolumn{2}{|c|}{ At harvest } \\
\hline & 20 DAE & 40 DAE & 60 DAE & At Harvest & $\begin{array}{c}\text { Seed } \\
\text { yield } \\
\text { plant }^{-1}(\mathrm{~g})\end{array}$ & $\begin{array}{c}\text { Seed } \\
\text { Yield (kg } \\
\left.\text { ha }^{-1}\right)\end{array}$ \\
\hline T1: Control & 0.65 & 4.79 & 11.17 & 12.24 & 3.77 & 1257.1 \\
\hline T2: Borax @ $2.5 \mathrm{Kg} \mathrm{ha}^{-1}$ & 0.77 & 5.76 & 13.42 & 15.65 & 4.17 & 1389.7 \\
\hline T3: Ammonium molybdate @ 1.5Kg ha ${ }^{-1}$ & 0.82 & 5.99 & 14.78 & 16.39 & 4.58 & 1526.0 \\
\hline T4: $\mathrm{Ni} \mathrm{Cl}_{2 .} 6 \mathrm{H}_{2} \mathrm{O} @ 1.0 \mathrm{Kg} \mathrm{ha}^{-1}$ & 0.72 & 5.52 & 13.22 & 15.11 & 4.02 & 1341.5 \\
\hline $\begin{array}{c}\text { T5: Borax @ 2.5\&Ammonium molybdate @ } \\
1.5 \mathrm{Kg} \mathrm{ha}^{-1}\end{array}$ & 0.88 & 7.08 & 16.05 & 18.45 & 5.92 & 1973.0 \\
\hline T6: Borax @ $\underset{h_{h}^{-1}}{2.5} \& \mathrm{Ni}_{2 .} 6 \mathrm{H}_{2} \mathrm{O} @ 1.0 \mathrm{Kg}$ & 0.86 & 6.67 & 15.11 & 16.98 & 5.68 & 1892.3 \\
\hline $\begin{array}{l}\text { T7: Ammonium molybdate @ } 1.5 \& \mathrm{Ni} \mathrm{Cl}_{2} . \\
6 \mathrm{H}_{2} \mathrm{O} @ 1.0 \mathrm{Kg} \mathrm{ha}^{-1}\end{array}$ & 0.87 & 6.80 & 15.34 & 17.63 & 5.74 & 1912.7 \\
\hline 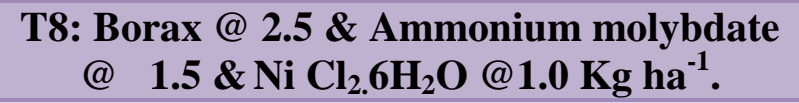 & 0.93 & 8.06 & 17.48 & 20.15 & 6.43 & 2144.5 \\
\hline SE $(\mathbf{m}) \pm$ & 0.02 & 0.13 & 0.5 & 0.27 & 0.12 & 40.4 \\
\hline $\mathrm{CD}(\mathbf{0 . 0 5})$ & 0.06 & 0.41 & 1.5 & 0.83 & 0.37 & 122.6 \\
\hline CV $(\%)$ & 4.5 & 3.7 & 5.5 & 2.9 & 4.20 & 4.2 \\
\hline
\end{tabular}


$\mathrm{B}$ and $\mathrm{Ni}$ individual application as basal had no effect on pod dry matter over control. This increase in pod dry matter can be attributed to the reason that increased photosynthetic efficiency increased the number and size of the pods and that resulted in increased pod dry matter. The same results were obtained by Valenciano et al., (2010). The increase in pod yield similar to present observations was reported by Singh et al., (2014) and Gad and Moez (2013).

\section{Total dry matter (g plant $\left.{ }^{-1}\right)$}

Micronutrient application in blackgram significantly increased the total biomass plant ${ }^{-1}$ over control at all stages of observation Table 3. At $20 \mathrm{DAE}$, among $\mathrm{T}_{2}$ to $\mathrm{T}_{8}$, application of $\mathrm{B}+\mathrm{Mo}+\mathrm{Ni}$ resulted in maximum amount of total biomass followed by $\mathrm{B}+\mathrm{Mo}$, which showed parity with $\mathrm{B}+\mathrm{Ni}$ and $\mathrm{Mo}+\mathrm{Ni}$ application. Minimum impact was noted in the treatment $T_{2}$ and $T_{4}$. Application of Mo alone increased the biomass superior to $\mathrm{T}_{4}$ and on par with $\mathrm{T}_{6}, \mathrm{~T}_{7}$, and $\mathrm{T}_{2}$. At $40 \mathrm{DAE}$, among $\mathrm{T}_{2}$ to $\mathrm{T}_{8}$, significantly higher biomass was noted in $\mathrm{T}_{8}$ and lower in $\mathrm{Ni}$ application. The next higher amount of biomass was found in $\mathrm{T}_{5}$, followed by $T_{7}$, which was on par with $T_{6}$. $B$ and Mo application alone resulted in total biomass production greater than $\mathrm{Ni}$ application and lower than combination treatments.

At 60 DAE, among $T_{2}$ to $T_{8}$ application of $\mathrm{B}+\mathrm{Mo}+\mathrm{Ni}$ resulted in maximum amount of total biomass followed by $\mathrm{B}+\mathrm{Mo}$, which showed parity with $\mathrm{B}+\mathrm{Ni}$ and $\mathrm{Mo}+\mathrm{Ni}$ application. Plants treated with $\mathrm{Mo}$ alone resulted in dry matter greater than $\mathrm{B}$ and $\mathrm{Ni}$ application alone and lower than combination treatments. At harvest significantly higher biomass than all other treatments was noted in $\mathrm{T}_{8}$. The total biomass obtained with $\mathrm{B}+\mathrm{Mo}$ application was in second place, followed by Mo+Ni application, which was on par with
$\mathrm{B}+\mathrm{Ni}$ application. The variation in total biomass between $T_{2} \& T_{3}$ and $T_{2} \& T_{4}$ was not to an extent of considerable level, superior to control and inferior to combination treatments. The increase in biomass with $T_{2}, T_{3}$ and $T_{4}$ was $1.3,1.3$ and 1.2 folds respectively, while that with $\mathrm{T}_{5}, \mathrm{~T}_{6}, \mathrm{~T}_{7} \& \mathrm{~T}_{8}$ was $1.5,1.4,1.4 \&$ 1.6 folds, respectively.

This effect of B, Mo and Ni in total dry matter seems to be on account of their impact on nutritional environment and involvement in various physiological processes in the plant system, which is considered to be prerequisites for better growth of the crop. Other dual treatments also favored plant dry matter and increase over control. Similar positive effects of $\mathrm{B}$, Mo and Ni on TDM have also been reported by Malik et al.,(2015) in mungbean, Karpagam and Rajesh (2014) in blackgram, Zahoor et al., (2013) in soybean and Gautam et al.,(2014).

\section{Seed yield: $\mathrm{kg} \mathrm{ha}^{-1}$}

The influence of micronutrient as basal application on seed yield of blackgram was found significant increased effects was observed Table 3. The lower seed yield was noticed in control and it showed parity with alone application of $\mathrm{Ni}\left(\mathrm{T}_{4}\right)$ and the significantly higher seed yield was noticed in $\mathrm{T}_{8}(\mathrm{~B}+\mathrm{Mo}+\mathrm{Ni})$. The next higher seed yield was noticed in $\mathrm{T}_{5}$ treatment $(\mathrm{B}+\mathrm{Mo})$ which showed parity with other combination treatments $\mathrm{Mo}+\mathrm{Ni}\left(\mathrm{T}_{7}\right)$ and $\mathrm{B}+\mathrm{Ni}\left(\mathrm{T}_{6}\right)$. Both Mo and $\mathrm{B}$ individual treatments increased the seed yield over control, higher in Mo treatment.

In summary, the results showed that application of micronutrients $\mathrm{B}$, Mo and $\mathrm{Ni}$ improve the seed yield. The maximum yield was observed in combined application of three micronutrients by 1.6, 1.5 and 1.5 folds respectively, where as $\mathrm{B}$ and Mo individual 
application increased the yield by 1.1 and 1.2 folds, respectively. $\mathrm{Ni}$ application alone had no increasing effect on seed yield. The synergetic influence of these micronutrients helps in augmenting nitrogen fixation and thus growth and yield of the crop. Working with different crops other researchers have also reported increased yield with application of B (Rajeev and Dinesh, 2014) and other micronutrients Mo (Kumar et al., 2018; Malik et al., 2015) and Ni (Gautam et al., 2014 and Naz et al., 2018).

Based on the results obtained in the present investigation it can be concluded that $\mathrm{B}+\mathrm{Mo}$ and $\mathrm{B}+\mathrm{Mo}+\mathrm{Ni}$ application increased the root biomass over control by 1.4 and 1.5 folds, respectively. Where as in other effective treatments (Mo, $\mathrm{B}+\mathrm{Ni}$ and $\mathrm{Mo}+\mathrm{Ni}$ ), root biomass increased by 1.3 folds. Stem biomass increased by 2.0, 1.8 folds with $\mathrm{B}+\mathrm{Mo}+\mathrm{Ni}$ and $\mathrm{Mo}+\mathrm{Ni}$ respectively. Compared to the application of $\mathrm{B}+\mathrm{Ni}$ and $\mathrm{Mo}(1.5 \& 1.6$ folds, respectively) $\mathrm{B}, \mathrm{Ni}$ and $\mathrm{B}+\mathrm{Mo}$ resulted in relatively higher increase (1.7 folds). Leaf biomass increased to an extent of 24.4 to 53.8 percent in $T_{5}$ to $T_{8}$ and 14.7 to 15.0 per cent in $\mathrm{T}_{2}$ to $\mathrm{T}_{4} . \mathrm{B}+\mathrm{Mo}$ and $\mathrm{B}+\mathrm{Mo}+\mathrm{Ni}$ application enhanced the pod dry matter by 1.4 and 1.5 folds, while $\mathrm{Mo}+\mathrm{Ni}, \mathrm{B}+\mathrm{Ni}$ and Mo application enhanced it by 1.3, 1.3 and 1.2 folds, respectively. The increase in total biomass with $\mathrm{T}_{2}, \mathrm{~T}_{3}$ and $\mathrm{T}_{4}$ was $1.3,1.3 \& 1.2$ folds while that with $\mathrm{T}_{5}, \mathrm{~T}_{6}, \mathrm{~T}_{7} \& \mathrm{~T}_{8}$ was $1.5,1.4$, $1.4 \& 1.6$ folds, respectively. The increase in seed yield over control (1257.1 kg ha $\left.{ }^{-1}\right)$ was high in combination of three nutrients $(2144.5$ $\mathrm{kg} \mathrm{ha} \mathrm{ha}^{-1}$ and B+Mo application (1973.0 $\mathrm{kg} \mathrm{ha}^{-1}$ ). B and Mo individual application also increased the yield by 1.1 and 1.2 folds respectively. $\mathrm{Ni}$ application alone had no influence on yield.

\section{References}

Bhuiyan, M. M. H., Rahman, M. M., Afroze, F., Sutradhar, G. N. C and Bhuiyan, M.
S. I. 2008. Effect of Phosphorus, Molybdenum and Rhizobium Inoculation on Growth and Nodulation of Mungbean Journal of Soil and Nature. 2(2): 25-30.

Gad, N and Moez, M. R. A. E. 2013. Influenced of Molybdenum on nodulation, Nitrogen fixation and yield of Cowpea. Journal of Applied Sciences Research. 9(3): 1498-1504.

Gautam, S., Pandey, S. N and Srivastava, M. N. 2014. Effect of $\mathrm{Ni}$ on seedling growth, physiological attributes in black gram (Vigna mungo) in leaves. International Journal of Current Research. 6(9): 8673-8676.

Karpagam, J and Rajesh, N. 2014. Molybdenum Application for Enhancing Growth, Yield and Soil Health on Green Gram (Vigna radiata L.). American-Eurasian Journal of Agricultural \& Environmental Sciences. 14 (12): 1378-1381.

Khan, N., Tariq, M., Ullah, K., Muhammad, D., Khan, I., Rahatullah, K., Ahmed, N and Ahmed, S. 2014. The Effect of Molybdenum and Iron on Nodulation, Nitrogen and Yield of Chickpea Genotypes (Cicer arietinum L). Journal of Agriculture and Veterinary Science. 7(1): 63-79.

Kumar, R., Tomar, G. S., Kumawat, N and Singh, S.P. 2018. Effect of varieties, plant density and molybdenum on yield and economics of blackgram under rainfed condition of Chhattisgarh. International Journal of Chemical Studies. 6(1): 1867-1870.

Malik, K., kumar, S and Arya, K. P. S. 2015. Effect of zinc, molybdenum and urea on growth and yield of mungbean (Vigna radiata L. Wilczek). Advance research journal of crop improvement. 6(1): 59-65.

Naz, H., Naz, A., Ayesha., Ashraf, $\mathrm{S}$ and Khan. H.H. 2018. Effect of Heavy 
Metals ( $\mathrm{Ni}, \mathrm{Cr}, \mathrm{Cd}, \mathrm{Pb}$ and $\mathrm{Zn}$ ) on Nitrogen Content, Chlorophyll, Leghaemoglobin And Seed Yield In Chickpea Plants in Aligarh City, U.P., India. International Journal of Current Microbiology and Applied Sciences. Special issue (7): 4387- 4399.

*Panse, M and Sukhatme, K. 1978. Statistical methods for Agricultural Workers. Indian Council of pearlmillet (Pennisetum glaucum L.). Effect on yield and yield components. Annals of Arid Zone. 37 (1): 59-67.

Rajeev Padbhushan and Dinesh Kumar. 2014. Influence of Soil and Foliar Applied Boron on Green Gram in Calcareous Soils. International Journal of Agriculture, Environment \& Biotechnology. 7(1): 129-136.

Singh, A.K., Khan, M.A and Srivastava, A. 2014. Effect of boron and molybdenum application on seed yield of mungbean. Asian Journal of Bio Scienc., 9(2): 169-172.

Singh, G., Agnihotr, R. K., Singh, D. K and
Sharma., R. 2013. Effect of $\mathrm{Pb}$ and $\mathrm{Ni}$ on root development and biomass production of black gram (Vigna mungo L.): overcoming through exogenous nitrogen application. International Journal of Agriculture and Crop Sciences. 5(22): 2689-2696.

Tripathy, S. K., Patra, A. K and Sumui, S. C. 1999. Effect of micronutrients on nodulation, growth, yield and nutrient uptake by groundnut. Indian Journal of Plant Physiology. 4(3): 201-209.

Valenciano, J. B., Boto, J. A and Marcelo, V. 2010. Response of chickpea (Cicer arietinum L.) yield to zinc, boron and molybdenum application under pot conditions. Spanish Journal of Agricultural Research. 8(3): 797-807.

Zahoor, F., Ahmed, M., Malik, M. M., Mubeen, K., Siddiqui, M. H., Rashee, M., Ansar, R and Mehmood, K. 2013. Soybean (Glycine max L.) response to micro-nutrients. Turkish Journal of Field Crops. 18(2): 134-138.

\section{How to cite this article:}

Shalem Raju, R., Y. Ashoka Rani, B. Sreekanth and Jyothula, D. P. B. 2019. Influence of Boron Molybdenum and Nickel on Total Dry Matter, Partitioning and Yield of Blackgram (Vigna mungo L. Hepper). Int.J.Curr.Microbiol.App.Sci. 8(12): 512-521. doi: https://doi.org/10.20546/ijcmas.2019.812.068 